\title{
PEMBERDAYAAN MASYARAKAT MELALUI PENDEKATAN COMMUNITY BASED TOURISM DI DESA KEPAKISAN DATARAN DIENG
}

\author{
Muafi $^{1)}$, Dyah Sugandini' ${ }^{2)}$, Christin Susilowati ${ }^{3)}$ \\ ${ }^{1}$ Fakultas Ekonomi, Universitas Islam Indonesia \\ ${ }^{2}$ Fakultas Ekonomi dan Bisnis, Universitas Pembangunan Nasional "Veteran" Yogyakarta \\ ${ }^{3}$ Fakultas Ekonomi dan Bisnis, Universitas Brawijaya Malang 3 \\ Email :muafi@uii.ac.id
}

\begin{abstract}
Abstrak
Dieng merupakan kawasan yang memiliki dataran tinggi. Dieng memiliki potensi wisata yang sangat menjanjikan dan sangat menarik untuk ditawarkan. Pendekatan community based tourism diharapkan bisa dipakai sebagai salah satu pendekatan yang bisa melibatkan partisipasi masyakarat lokal bekerjasama dengan pemerintah, perusahaan dan perguruan tinggi. Kekuatan pendekatan ini adalah bertumpu pada masyarakat dan berorientasi pada lingkungan alam serta menjunjung tinggi nilai budaya tradisional dengan tetap mempertahankan kearifan lokal. Objek pengabdian ini dilakukan di Desa Kepakisan, Kecamatan Batur, Banjarnegara. Tujuan kegiatan pengabdian masyarakat ini adalah pengabdi beserta aparat pemerintah dan masyarakat lokal melakukan; (1) pemetaan potensi wisata dan penentuan skala prioritas lokasi wisata, (2) menjembatani pendanaan melalui dana program tanggung jawab social lingkungan (TJSL) BUMN (Perum BULOG), (3) pemberdayaan masyarakat dengan pembersihan telaga dan melakukan pelatihan UKM olahan makanan kepada mayarakat. Metode yang digunakan adalah pemberdayaan masyakarat dengan melibatkan secara langsung aparat pemerintah dan masyarakat lokal melalui pendekatan community based tourism. Hasilnya masyarakat Desa Kepakisan memiliki telaga yang bersih dan bermanfaat untuk kegiatan pemancingan, lokasi berkumpulnya warga untuk kegiatan nasional, penjualan usaha makanan dan minuman di lokasi setempat, pengairan untuk perkebunan dan destinasi wisata sehingga bisa menggerakkan kegiatan perekonomian masyarakat lokal.
\end{abstract}

Kata Kunci : pemberdayaan, CBT, pelatihan

\section{PENDAHULUAN}

BUMN merupakan salah satu perusahaan yang bertujuan sebagai agent of development, disamping juga untuk mencari keuntungan. Perusahaan ini merupakan perusahaan milik negara yang dibeentuk dengan Undang-Undang. Proses penyertaan adalah Modal Negara karena berasal dari uang rakyat dan untuk rakyar. BUMN disebut sebagai organisasi hibrida dikarenakan perusahaan BUMN mengelola dua jenis dana yakni dana publik yang berasal dari keuangan negara dan serta dana dari pihak swasta. Hal ini menandakan bahwa perusahaan BUMN memiliki dua fungsi yang saling bertentangan satu sama lainnya. Di satu sisi, perusahaan BUMN menjalankan bisnis dengan mengikuti tata kelola yang baik dan transparan. Di sisi lain, perusahaan BUMN juga harus dapat memberikan pelayanan pada public dengan baik. Saat ini semakin banyak perusahaan BUMN di Indonesia yang terlibat dalam sejumlah proyek strategis nasional, melakukan ekspansi operasi di sejumlah kawasan strategis dan memperoleh pengakuan kinerja di tingkat internasional. BUMN memiliki sumbangan yang rekatif besar untuk menopang perekonomian nasional pada umumnya dan negara pada khususnya (http://www.bumn.go.id/hutamakarya/berita/0BUMN-sebagai-Mesin-Pertumbuhan-Ekonomi, akses 14 November 2017).

Peraturan Menteri BUMN Nomor 5 Tahun 2007 telah mengatur tentang Program Kemitraan dengan Usaha Kecil dan Bina Lingkungan (PKBL). Pada beberapa BUMN program Tanggung Jawab Sosial Lingkungan (TJSL) perusahaan dipakai sebagai salah satu jenis program PKBL, bahkan sering identik dengan istilah yang umum digunakan di perusahaan swsata yakni program Corporate Social Responsibility (CSR). Konsep TJSL ini seharusnya perusahaan memiliki tanggung jawab yang harus harus berpijak pada triple bottom lines, yaitu berupa: finansial, sosial dan lingkungan (Muafi, 2015a; 
Suparyono, 2012). Ketiga aspek tersebut sangatlah penting mengingat perusahaan tidak boleh hanya berorientasi pada aspek keuangan saja tetapi perlu juga didukung dengan aspek sosial dan lingkungan. Hal ini dikarenakan pengaruh perusahaan terhadap lingkungan masyarakat dapat menimbulkan berbagai persoalan sosial dan lingkungan karena perusahaan memiliki aktivitas yang tidak terlepas dari lima kegiatan berikut antara lain (Hadi, 1995);

1. memanfaatkan sumber daya alam sebagai bagian dari proses produksinya;

2. memiliki tingkat persaingan antar organisasi di pasar yang sama;

3. menciptakan kesempatan kerja dengan menyerap tenaga kerja lokal;

4. melakukan transformasi karena ekstraksi bahan baku atau penyimpanan limbah produk dari alam;

5. berkewajiban untuk meningkatkan kesejahteraan masyarakat dengan tetap memperhatikan kelestarian lingkungan

Kawasan Dieng merupakan suatu kawasan yang terbentuk akibat adanya aktivitas gunung api sehingga keberadaan tanah di Kawasan Dieng merupakan tanah yang sangat subur (https://bappeda.wonosobokab.go.id/kawasandieng/, akses 13 November 2017). Kesuburan tanahnya ini dimanfaatkan oleh masyarakat sebagai lahan pertanian. Dieng juga memiliki kondisi morfologi dan geologi yang cukup unik. Situasi dan kondisi ini tanpa disadari oleh masyarakat dalam jangka panjang akan bisa menimbulkan erosi dan longsor yang sangat intensif dan berbahaya bagi masyarakat. Tuntutan ekonomi masyarakat menyebabkan masyarakat kadangkala melupakan pentingnya kelestarian lingkungan dan konservasi lingkungan. Daerah dengan kemiringan curam banyak dimanfaatkan oleh masyarakat untuk menanam segala jenis pertanian dan perkebunan secara optimal meskipun kadangkala tidak memikirkan bahaya erosi dalam jangka panjang. Kawasan Dieng ini merupakan salah satu objek yang dijadikan sebagai salah satu kawasan oleh BUMN Perum BULOG untuk menyalurkan dana TJSL karena kawasan ini memiliki permasalahan yang kompleks dan layak untuk dibantu.
Kepadatan penduduk rata-rata di Kawasan Dieng mencapai 100 jiwa/km2 dengan pemilikan lahan yang rendah yaitu rata-rata sebesar 0,1 ha. Desa yang paling padat penduduknya adalah Desa Dieng Kecamatan Kejajar yang mencapai 190 jiwa / km 2 . Tingginya jumlah kepadatan penduduk dan kepemilikan tanah yang semakin rendah menyebabkan berubahnya fungsi tanah menjadi kawasan budidaya (Andriyana, 2007). Kawasan Dieng memiliki potensi yang tidak dimiliki oleh kawasan lain, antara lain; potensi ekonomi, potensi perkebunan, pertanian, wisata dan pemandangan alam yang sangat indah.

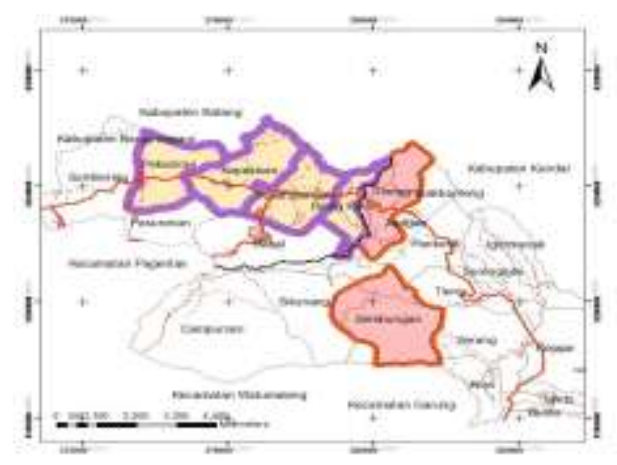

\section{Pembelajaran Berbasis Masyakarat (Community Based-Learning-Cbl)}

Konsep pembelajaran berbasis masyarakat adalah konsep pembelajaran yang berbasis pada peran serta masyarakat. Masyarakat mengembangkan program-program yang bisa bermanfaat untuk masyarakat dan melaksanakannya secara bersamasama. Pihak lain yakni pemerintah, perusahaan dan perguruan tinggi bisa dijadikan sebagai mitra dalam program-program pembelajaran masyarakat. Fungsi dari pihak mitra adalah memfasilitasi, memberikan dana dan mendampingi pelaksanaan program tersebut tanpa adanya kepentingan individu atau kelompok. Owens dan Wang (1996) mendefinisikan pembelajaran berbasis masyarakat adalah "seperangkat strategi pengajaran yang luas yang memungkinkan remaja dan orang dewasa untuk belajar apa yang ingin mereka pelajari dari kelompok masyarakat manapun". Peserta pembelajaran masyarakat bisa berasal dari segala usia dan segala lapisan masyarakat. Bisa melakukannya dengan 
mengidentifikasi program dan memanfaatkan sumber daya yang tidak terbatas yang dimiliki untuk mendukung program mereka.

Owens (1994) mengenalkan A Model for Restructuring Education for the 21st Century dengan mengidentifikasi beberapa asumsi penting sebagai dasar atau landasan untuk pembelajaran masyarakat, yakni;

- Pendidikan harus dipandang sebagai rangkaian dari prasekolah melalui pendidikan seumur hidup bagi orang dewasa,

- Belajar adalah apa yang kita lakukan untuk diri kita sendiri. Oleh karena itu, dibutuhkan keterlibatan penuh dari pembelajar serta guru / mentor.

- Pekerjaan di masa depan akan membutuhkan tidak hanya pendidikan yang lebih banyak, tapi juga jenis pendidikan yang berbeda, termasuk critical thinking, kerja tim, dan kemampuan untuk menerapkan pengetahuan,

- Orang dewasa perlu dilibatkan dalam urusan masyarakat dengan tujuan untuk menyeimbangkan pekerjaan, keluarga dan tanggung jawab pada masyarakat,

- Masalah yang mempengaruhi peserta didik saat ini jauh lebih luas daripada yang bisa diatasi sendiri. Keterlibatan keluarga, perusahaan, tenaga kerja, masyarakat, dan instansi lainnya adalah penting,

- Bantuan kelompok masyarakat berlaku dengan melihat kebutuhan akan adanya perubahan sehingga mereka merasa diberdayakan untuk memandu perubahan ini. Tanpa Visi yang jelas, maka pelaksanaan program tidak akan terjadi meskipun didukung dengan sumber daya dan staf yang baik.

Dapat disimpulkan bahwa pembelajaran berbasis masyarakat (community based learning) adalah model pembelajaran yang melibatkan masyarakat agar berpartisipasi dalam perencanaan, pelaksanaan dan evaluasi program masyarakat dengan tujuan membantu masyakarat pembelajar untuk mengimplementasikan antara pengetahuan dan keahlian yang diterima dalam kehidupan bermasyarakat. Pembelajaran berbasis masyarakat harus memiliki Visi dan Misi yang jelas dan didukung dengan sumber daya yang dimiliki dalam masyakarat. Pemberdayaan berbasis masyarakat ini sudah seharusnya didukung mitra dari pihak luar yakni pemerintah, perusahaan dan perguruan tinggi.

\section{Pembelajaran Berbasis Wisata (Community Based Tourism--CBT).}

Dalam pengembangan wisata di Kawasan Dieng, khususnya di Desa Kepakisan konsep pembelajaran berbasis masyarakat (Community Based Learning) akan dikaitkan dengan konsep pembelajaran berbasis wisata (Community Based Tourism-CBT). Hausler (2005) mendefinisikan CBT sebagai program pariwisata dengan memberikan peluang kepada masyarakat setempat/lokal untuk memiliki keterlibatan dan pengendalian dalam perencanaan, pelaksanaan dan evaluasi manajemen pariwisata. Ada tiga unsur penting yang perlu dilaksanakan adalah; keterlibatan masyarakat lokal, pemerataan akses ekonomi bagi masyakarat, dan capacity building.

Menurut Nurhidayati dan Fandeli (2012) secara umum prinsip dasar Community Based-Tourism adalah mengikutsertakan anggota masyarakat dalam memulai setiap program pariwisata. Community Based-Tourism merupakan wisata yang dikelola dan dimiliki oleh masyarakat dan untuk masyarakat. Masyakarat diharapkan dapat meningkatkan kesadaran mereka dan kemauan untuk melakukan pembelajaran tentang pariwisata sehingga diharapkan bisa mengelola wisata untuk meningkatkan kesejahteraan masyarakat lokal. Dalam upaya agar Desa Kepakisan bisa berhasil maka masyarakat dituntut berperan aktif dalam usaha kepariwisataan desa mereka dengan memanfaatkan potensi dan kemampuan yang mereka miliki seperti yang disarankan oleh Michael dan Reid (2007).

Harus di sadari bahwa saat ini keinginan wisatawan semakin beragam. Demikian juga kesadaran akan pelestarian lingkungan dan tingkat kompetisi destinasi menjadikan para pelaku wisata khususnya dna masyarakat secara umum harus berbenah. Terkait dengan kesadaran wisata berbasis lingkungan, faktor sikap pelaku wisata dan wisatawan juga ditentukan oleh seberapa baik sikap pelaku maupun wisatawan dalam memandang lingkungannya. Semakin memiliki orientasi yang baik pada lingkungannya, maka pelestarian lingkungannya juga akan semakin baik (Sugandini, 
Rahatmawati dan Arundati, 2018). Pengetahuan yang baik terhadap lingkungan yang menjadi destinasi wisata akan berpengaruh pada kemauan pelaku untuk merubah perilakunya ke arah lingkungannya (Sugandini, Rahatmawati dan Istanto, 2017).

Wisata alam sebenarnya merupakan jenis wisata minat khusus yang harus dikemas secara menarik dan komprehensif sehingga menjadikan wisatawan nusantara maupun mancanegara tertarik untuk berkunjung dan bertransaksi ulang. Strategi pengelolaannya harus dikemas dengan melibatkan pengunjung untuk melakukan interaksi dengan alam lingkungan serta mempelajari budaya masyarakat lokal sehingga memiliki pengalaman yang menarik dan berkesan. Daya tarik tersebut bisa ditonjolkan sebagai salah satu jenis paket wisata di mana di dalamnya memerlukan keterlibatan langsung peran masyarakat lokal. Sebenarnya di Kawasan Dieng beberapa paket wisata tersebut sudah ada misalnya pemotongan rambut "Gembel" dan pentas seni tradisional Dieng. Hanya saja perlu dikemas dan disosialisasikan secara terus menerus kepada pihak luar serta perlu keterlibatan aktif dari masyakarat. Selain itu dalam rangka menunjang keberhasilan pariwisata maka perlu didukung oleh UKM lokal yang bisa mengenalkan dan menjual produk sesuai dengan kearifan lokal dan potensi sumber daya alam yang dimiliki. Seperti diketahui bahwa UKM bisa menggerakkan potensi ekonomi masyarakat dan terbukti bisa membantu untuk menopang perekonomian negara. (Muafi dan Roostika, 2014; Muafi, 2009; Muafi, 2012; Muafi 2015a; Muafi., Roostika, Wijayani and Poerwanto, 2016; Muafi., Susilowati, and Suparyono, 2016b Muafi, 2016; Muafi, 2015b; Muafi, 2016; Muafi, 2015c)

Citra dieng sebagai destinasi wisata, secara langsung juga dipengaruhi oleh bagaimana kualitas yang diberikan oleh setiap destinasi yang dituju. Sehingga pembenahan terhadap sarana dan prasarana yang mendukung destinasi wisata di Dieng perlu penangan lebih baik (Susilowati dan Sugandini, 2018). Sehingga pelatihan kepada para pelaku wisata di Dieng perlu ditingkatkan, dan sarana prasarana penunjang destinasi wisata juga perlu diperbaiki. Semakin baik kesiapan destinasi wisata dalam melayani pelanggan maka akan semakin meningkatkan loyalitas wisatawannya. Loyalitas bisa diwujudkan melalui komunikasi dari mulut ke mulut yang relatif baik (Sugandini, Benny dan Muafi, 2017).

\section{METODE KEGIATAN}

Pengabdian masyarakat ini melibatkan seluruh aparat pemerintah, perusahaan dan masyarakat melalui studi literature, interview, focus group discussion serta melibatkan peran langsung masyarakat dan pemerintah. Kegiatan diarahkan dengan melakukan pemetaan destinasi wisata yang ada di Kawasan Dieng khussunya di Desa Kepakisan, Kecamatan Batur, Kabupaten Banjarnegara, Jawa Tengah. Juga dilakukan dengan pembenahan sarana dan prasarana salah satu objek wisatawan, disamping juga dilaksanakan dengan pemberian pelatihan usaha kecil melalui usaha makanan seperti keripik aneka daun, keripik singkong, ayam krispi.

Kegiatan ini dilakukan selama 3 bulan dan didukung oleh Kepala Desa Kepakisan dan seluruh aparatnya, juga tokoh masyarakat, serta masyarakat (bapak, ibu dan pemuda/pemudi) Desa Kepakisan. Pemberdayaan masyarakat dilakukan dengan mengundang stakeholders untuk mendiskusikan pemetaan lokasi wisata dan keberadaan industrikecil yang bisa mendukung adanya potensi wisata di Desa Kepakisan. Berdasarkan hasil diskusi dan FGD yang panjang dan melelahkan akhirnya disepakati bahwa kegiatan pengabdian masyarakat ini diprioritaskan di Telaga Swiwi. Kegiatan pertama akan dilaksanakan dengan pembersihan telaga dan pemberian ikan tawar untuk pemancingan. Ke depannya aparat desa dan masyarakat berharap bisa mendirikan Balai Ekonomi Desa (Balkondes) yang diharapkan bisa memberikan manfaat dalam jangka panjang. Pelaksanaan kegiatan pembersihan telaga dan pelatihan ini terlaksana berkat kerjasama antara pengabdi dan masyarakat Desa Kepakisan serta didukung pendanaan dari dari Perum BULOG sebagai salah satu BUMN yang memiliki program tanggung jawab social lingkungan (TJSL) perusahaan. 


\section{HASIL DAN PEMBAHASAN}

Sebelum melakukan pemetaan, maka digambarkan profil dan potensi Desa Kepakisan.

\section{Profil Dan Potensi Desa Kepakisan}

Desa Kepakisan merupakan salah satu desa di wilayah dataran tinggi Dieng yang mempunyai luas wilayah 719.373 hektar dengan ketinggian dari permukaan air laut 1863 mdpi. Jumlah penduduk 2972 jiwa (1407 laki-laki dan 1565 perempuan) dengan 821 kepala keluarga. Mata pencaharian penduduk 1135 petani dan 1346 buruh tani (Data Statistik Desa Kepakisan, 2016). Desa Kepakisan menjadi sangat potensial untuk dikembangkan terutama dari segi pertanian dan wisatanya, karena:

1. Kawasan Desa Kepakisan merupakan zona dua pengembangan pariwisata Dieng dan penyangga Dieng. Perlunya kawasan ini dikembangkan khususnya dari aspek pariwisata karena akan membantu konservasi lahan melalui pengalihan bidang usaha dari sektor pertanian ke sektor pariwisata. Desa Kepakisan merupakan jalur utama dan sebagai pintu gerbang wisatawan yang berasal dari pantai utara jawa (pantura).

2. Desa Kepakisan memiliki Telaga Swiwi. Telaga Swiwi ini biasanya dipakai sebagai sumber mata air baku untuk konsumsi dan pertanian (sebagai tandon air) juga bisa dimanfaatkan untuk rest area.

3. Penduduk Desa Kepakisan termasuk penduduk miskin dan sekitar 50 persen penduduknya hanya bekerja sebagai buruh tani.

Oleh karena itu, Desa Kepakisan sangat membutuhkan program TJSL khususnya dalam program kemitraan dan bina lingkungan guna mengentaskan kemiskinan dan untuk mengatasi permasalahan-permasalahan yang ada diantaranya:

- Lahan kritis. Tanah di desa ini mulai mengalami kejenuhan dan kurang subur sehingga sudah mulai berkurang produktivitasnya.

- Berpotensi longsor dan memiliki tanah gundul karena telah dieksploitasi untuk lahan pertanian.

- Banyaknya pengangguran dan tingginya tingkat kemiskinan

- UKM kurang berdaya dari aspek modal, teknologi dan keahlian
- Wisata berbasis agrowisata sangat tidak berkembang dan kurang bisa dioptimalkan

- Tidak adanya integrated farming system di Desa Kepakisan menjadikan desa ini tertinggal dari sisi perekonomian. Padahal di desa Kepakisan sangat memungkinkan dilakukan system tersebut. Sistem yang menggabungkan kegiatan pertanian, peternakan, perikanan, kehutanan dan lainnya dalam satu lahan sangat memungkinkan dilakukan di Desa ini karena memang memiliki keseluruhan potensi tersebut.
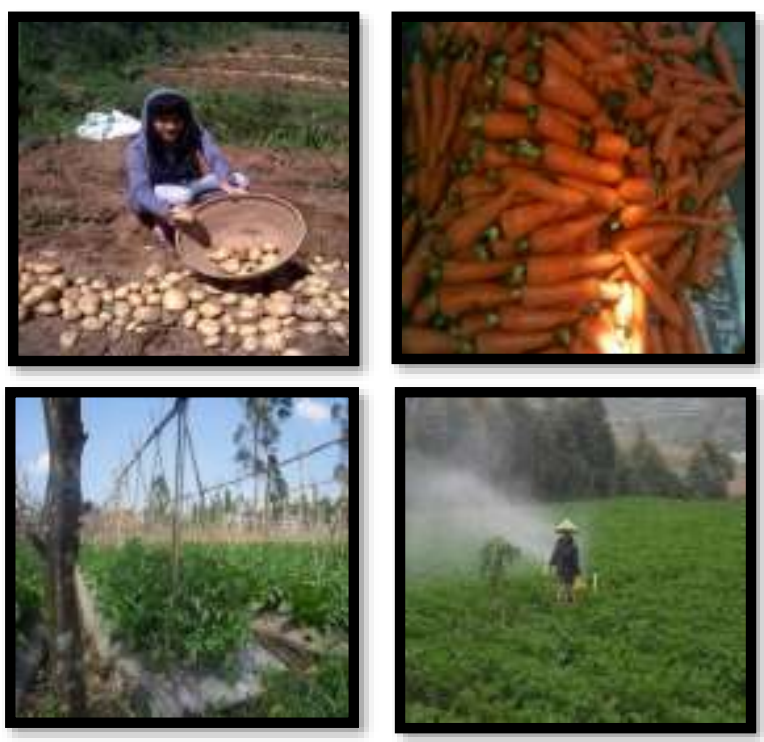

Gambar 1. Beberapa contoh hasil pertanian dan sayuran di Desa Kepakisan

Berdasarkan hasil diskusi dengan pihak kelurahan dan tokoh masyarakat serta kelompok sadar wisata setempat maka pengabdi mengidentifikasi beberapa potensi objek wisata Desa Kepakisan. Objek- objek wisata yang menjadi daya tarik wisatawan untuk datang ke Desa wisata Kepakisan, dapat dibagi kedalam tiga kelompok yakni;

1. Wisata Alam dan buatan mencakup; Telaga Swiwi, Kawah Sileri, Curug Sirawe, Wisata pemandian air panas D'Qiano, Agrowisata dan Living Culture masyarakat Dieng.

2. Wisata Budaya. Beberapa daya tarik budaya yang bisa ditonjulkan adalah; ruwatan rambut gembel, Dieng Culture festival dan Jazz Di Atas Awan.

3. Wisata berkaitan dengan pemberdayaan UKM mencakup; Batik Kayu Dewa, Miniatur Candi, 
purwaceng, keripik kentang, manisan Carika, Selai Carika, Grobi kentang, dan sebagainya.

\section{Pelaksanaan Kegiatan}

Kegiatan pengabdian masyarakat diprioritaskan pada objek wisata Telaga Swiwi. Telaga ini diprioritaskan mengingat beberapa potensi diharapkan bisa dikembangkan dan diharapkan bisa memberikan kemanfaatan dalam jangka pendek dan jangka panjang. Dilaksanakan dengan melakukan pemberdayaan kepada masyarakat dengan cara;

1. Pembersihan Telaga Swiwi

2. Pemberian ikan tawar untuk pemancingan

3. Rancangan pembuatan Balkondes

(Balai

Ekonomi Desa) di Telaga Swiwi

4. Pelatihan olahan makanan dan sayuran

Kegiatan dilaksanakan selama 3 bulan melibatkan aparat Desa dan masyarakat setempat. Masyarakat sangat antusias dalam melaksanakan kegiatan tersebut. Hal ini dikarenakan selama ini Telaga Swiwi cenderung kurang bisa dioptimalkan. Dengan pembersihan dan pemberian ikan tawar untuk pemancingan maka diharapkan bisa memberikan dampak positif untuk tumbuhnya kegiatan perekonomian masyarakat setempat. Disamping itu telaga ini bermanfaat juga sebagai sumber mata air baku untuk konsumsi dan pertanian (sebagai tandon air).

Kementerian BUMN mengutamakan konsep Balai Ekonomi Desa (Balkondes) yang bertujuan untuk memberdayakan perekonomian masyarakat di sekitar kawasan wisata. Keberadaan Balai Ekonomi Desa (Balkondes) bisa menjadi salah satu komponen utama dalam program BUMN Hadir Untuk Negeri. Hal ini diharapkan dapat menjadi salah satu motivasi bagi warga masyarakat untuk bergerak mengembangkan industri rumah tangga dalam bisnis pariwisata di kawasan tertentu (http://www.bumn.go.id/berita/0-Sinergi-BUMNuntuk-Pariwisata, akses 14 november 2017). Keberadaan Balkondes diharapkan memberi manfaat bagi masyarakat sehingga mereka tidak lagi menjadi penonton jutaan wisman yang berkunjung ke wilayahnya. Balkondes biasanya akan dilengkapi pendopo utama, limasan, artshop, gazebo, musholla, dapur, toilet, panggung utama dan homestay. Masyarakat bisa memanfaatkan semua fasilitas yang ada untuk meningkatkan potensi desa wisata. Harapannya pembangunan Balkondes bisa didukung dan dikaitkan dengan destinasi wisata sekitarnya yaitu: Telaga Swiwi, Curug Sirawe, Wisata kolam renang air panas D’Qiano, Kawah Sileri, Jogging track, wisata memancing, petik sayur mayur, menginap di rumah penduduk dengan menikmati budaya lokal, wisata kuliner khas dieng dan wisata kuliner air tawar, outbond, agrowisata, wisata bunga Lili, wisata buah straberry, wisata edukasi (penangkaran bibit dan benih sayur mayur), dan wisata alam lainnya.
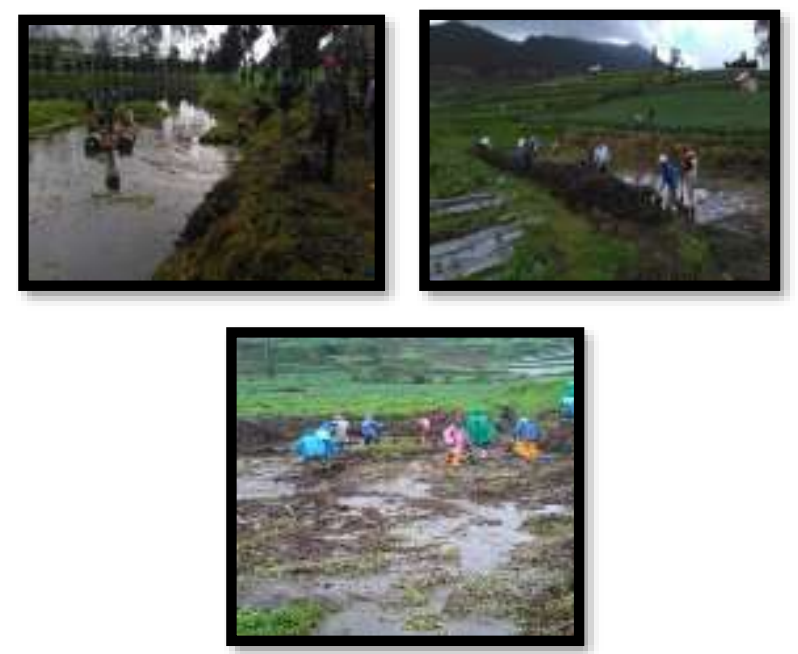

Gambar 2. Tim Pengabdi bersama masyarakat melakukan pembersihan telaga

Untuk menunjang program tersebut, maka Balai Ekonomi Desa bisa digunakan sebagai sarana pemberdayaan masyarakat. Beberapa program yang bisa diusulkan antara lain;

1. Membangun dan memperbaiki sarana prasarana yang bisa menunjang kegiatan pertanian untuk produksi maupun lainnya seperti pembuatan penangkaran bibit dengan screenhouse, membuat demplot-demplot pertanian dan lainnya.

2. Mempersiapkan SDM lokal agar memiliki kesadaran wisata serta mampu memberdayakan dirinya untuk ikut serta meningkatkan roda perekonomian keluarga.

3. Membuat agrowisata agar potensi agrowisata bisa semakin dikenal oleh masyarakat luas

4. Community Based Tourism dilakukan dengan melibatkan partisipasi masyarakat dalam:

- Pembuatan sarana prasarana integrated farming system 
- Pelatihan manajemen dan bisnis termasuk pelatihan yang bertujuan untuk penguatan dan pengembangan kelembagaan

- Pembuatan pekat wisata Desa wisata Kepakisan

- Membentuk kelompok-kelompok masyarakat sadar wisata di desa Kepakisan

- Melakukan pendampingan pemetaan desa wisata, analisis karakteristik dan ukuran keberhasilan community based-tourism, serta identifikasi kelompok pelanggan dari mancanegara maupun lokal

Selanjutnya untuk menunjang potensi destinasi wisata tersebut, maka pengabdi juga melakukan kegiatan berupa pelatihan dan pendampingan pembuatan usaha makanan seperti keripik aneka daun, keripik singkong, dan ayam krispi. Pelatihan dilaksanakan dengan memberikan cara dan teknik untuk membuat beberapa makanan dari aneka daun, keripik singkong dan ayam krispi. Pengabdi juga memberikan pelatihan dari aspek manajemen kauangan dan akuntansi, pemasaran dan pengelolaan usaha. Kegiatan ini di ikuti oleh beberapa ibu-ibu dari kelompok tani dan kelompok arisan dan RT dari masyarakat Desa Kepakisan. Pengabdi mendatangkan juga tenaga ahli yang sudah berpengalaman, khususnya dari aspek teknik pengolahan makanan dengan memanfaatkan sumber daya alam yang dimiliki daerah setempat serta teknologi sederhana. Masyarakat khususnya ibu-ibu sangat antusias dalam mengikutinya dan bisa mempraktikkan pelatihan yang telah di ikutinya.
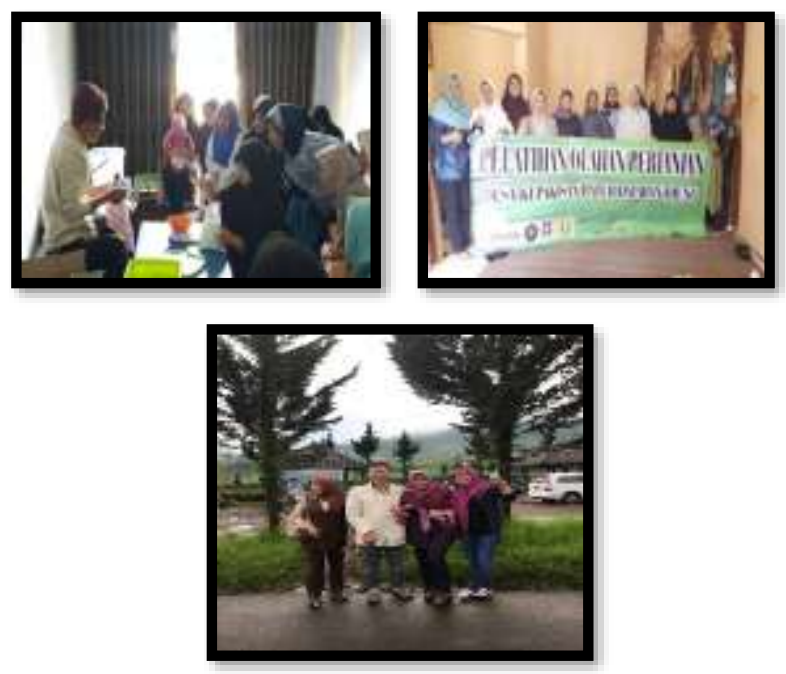

Gambar 2. Tim Pengabdi bersama pejabat Perum BULOG

\section{KESIMPULAN} melakukan pelatihan dan kunjungan

Pelaksanaan kegiatan masyarakat dapat berjalan dengan lancar. Aparat Desa dan perangkatnya serta masyarakat sangat antusias dalam mengikuti kegiatan tersebut. Mereka semakin menyadari tentang potensi destinasi wisata yang ada di Desa Kepakisan.

1. Dukungan dari pihak pemerintah, perusahaan dan perguruan tinggi sangat diharapkan bisa semakin meningkatkan kunjungan wisatawan lokal maupun mancanegara ke Dieng khususnya ke Desa Kepakisan, Kecamatan Batur, Kabupaten Banjarnegara, Jateng.

2. Bantuan teknologi sangat diharapkan bisa menumbuhkembangkan usaha kecil dan menengah yang ada di Desa Kepakisan, baik teknologi tepat guna maupun teknologi informasi.

3. Pendampingan sangat dibutuhkan oleh masyarakat dalam jangka panjang dan tidak hanya bersifat sporadis atau ad hoc.

\section{REFERENSI}

Andriana, R. (2007). Evaluasi Kawasan Lindung Dataran Tinggi Dieng Kabupaten Wonosobo, Tesis, Program Magister Ilmu Lingkungan, Universitas Diponegoro. Semarang,

Anonim (2016). Data statistik Desa Kepakisan Hadi, N. (1995). Corporate Social Responsibility, Graha Ilmu, Yogyakarta.

Hausler, N. (2005). Definition of Community Based Tourism. Tourism Forum International at The Reisepavillon. Hanover, February, 6, 2005.

Mitchell, R. E \& Reid, D. G. (2001). Community integration: Island tourism in Peru. Annals of Tourism Research , 28(1), 113-139.

Muafi \& Roostika, R. (2014). Organizational Performance and Competitive Advantage Determinants of Creative SMEs, European Journal of Economics and Management, Vol.1 No.2, p. 7-25.

Muafi (2009). The Effect of Alignment Competitive Strategy, Culture, and Role Behavior on Organizational Performance in Service Firms, The International Journal of Organizational Innovation (IJOI), Volume 2 Number 1 Summer 2009, page 106-133.

Muafi (2012). Pola Hubungan Inovasi Organisasi, People Equity dan Kinerja UKM, Ekuitas, Vol.16, No.2, p. 230-244. 